\section{Role of Catecholamines in the Amphetamine Excitatory Response}

WHETHER amphetamine exerts its behavioural excitatory action in the brain directly or indirectly by interference or synergism with the catecholamines (noradrenaline and dopamine) is open to debate ${ }^{1,2}$. The advent of $\alpha$-methyl para-tyrosine ${ }^{3}(\alpha$-MPT), which inhibits the in vivo synthesis of 3,4-dihydroxyphenylalanine (DOPA) - the physiological precursor of the catecholamines-offers a new way of investigating this problom.

Spoctor et al. ${ }^{3}$ showed that after treatment with $\alpha$-MPT the content of noradrenaline in the brain and other organs gradually decreased, and after ropeated doses it finally bocame impossible to detect noradrenaline. We found, using twelve rats, that even $3-5 \mathrm{~h}$ after one dose of $\alpha$-MPT $(75-200 \mathrm{mg} / \mathrm{kg}$ subcutancously), amphetamino ( $3 \mathrm{mg} / \mathrm{kg}$ subcutaneously-referring to the $d$-amphetamine base) elicited little motor activity. The rats sat quietly and performed some grooming actions; with the lower doses, however, they also walked forwards. After repeated doses of $\alpha$-MPT, even $6 \mathrm{mg}$ of amphetamine $/ \mathrm{kg}$ given subcutaneously was antagonized (Table 1).

Table 1. Behaviourad EFfects of Amphetamine and $l$-DOPA in Rats PRETREATED WITII REPEATED DOSES OF $\alpha$-METHYL paraTYROSINE

All rats received subcutaneously $100 \mathrm{mg} / \mathrm{kg} \alpha$-MPT 9,6 and $3 \mathrm{~h}$ before treatment with amphetaminc and DOYA

\begin{tabular}{|c|c|c|c|c|}
\hline & $\begin{array}{c}\text { Dose } \\
(\mathrm{mg} / \mathrm{kg} \text { s.c. })\end{array}$ & $\begin{array}{l}\text { No. } \\
\text { of } \\
\text { rats }\end{array}$ & $\begin{array}{l}\text { No. of rats } \\
\text { showing } \\
\text { stereotype } \\
\text { behaviour* }\end{array}$ & $\begin{array}{l}\text { Level of } \\
\text { motor } \\
\text { activity }\end{array}$ \\
\hline Amphetamine & 6 & 6 & $0 / 6$ & Low $†$ \\
\hline $\begin{array}{l}\text { Amphetamine } \\
+l \text {-DOPA } \\
l \text {-DoPA }\end{array}$ & $\begin{array}{l}200 \\
400\end{array}$ & $\begin{array}{l}6 \\
6\end{array}$ & $\begin{array}{l}6 / 6 \\
0 / 6\end{array}$ & $\begin{array}{l}\text { High } \\
\text { Lowई }\end{array}$ \\
\hline
\end{tabular}

* Constant sniffing, licking or biting of cage netting wire.

$\uparrow$ Sat quietly most of the time. Performed some grooming and 50-70 min after amphetamine walked forward a little. Very little sniffing.

$\ddagger$ Vigorous sniffing and biting for more than $30 \mathrm{~min}$, walked forwards, backwards and circled about, but no grooming.

\$ Sat or lay quietly, grooming, very little sniffing.

Amphetamine, when given alone, always produced marked hyperactivity and continuous, stereotypo sniffing, licking or biting of the wire netting of the cage ${ }^{2,4,5}$ (moro than 200 rats were observed when doses of $1 \cdot 5-30 \mathrm{mg} / \mathrm{kg}$ were given subcutaneously). With dosos larger than $3 \mathrm{mg} / \mathrm{kg}$, forward walking was completely abolished for a while; the rats performed their sterootype activity without moving, or they only walked backwards ${ }^{4,5}$. Grooming actions were not observed ${ }^{5}$.

The experimental results in Tablo 1 strongly suggest that the antagonistic effect of $\alpha$-MPT on amphetamine is due to the inhibition of DOPA-synthesis and not to some other action of the drug. Doses of up to $400 \mathrm{mg} \mathrm{l-DOPA/}$ $\mathrm{kg}$ givon subcutaneously (nine rats treated) also had little effect on the gross behaviour of rats which had not received any protreatment. A largor dose of $l$-DOPA $(1,200 \mathrm{mg} / \mathrm{kg}$ given subcutanoously), however, produced hyperactivity and stereotype behaviour similar to that seen after amphetamine (ten rats) ${ }^{6}$.

As inhibition of amphetamine-induced stereotype behaviour would seem to be a characteristic property of neuroleptic drugs ${ }^{5,7}, \alpha$-MPT may possess antipsychotic activity. Here it is interesting to note that $\alpha$-MPT, like perphenazin $\theta^{5}$, not only antagonized the abnormal stereotype activity but also simultaneously increased normal activitios such as grooming and, in lower doses, forward walking.

Since this report was completed we have loarned that Woissmann and Koe (Life Sci., 4, 1037; 1965) have also observed the antiamphetamine offect of $\alpha-\mathrm{MP} T$, but wore unable to reactivato tho rats with DOPA. In our experiments, however, the rats became active $75-90 \mathrm{~min}$ after the injection of amphetamine + DOPA while Weissmann and Koe only observed thoir animals $60 \mathrm{~min}$ after the injection.
Wo thank Merck, Sharp and Dohme for a gonerous. supply of $\alpha$-MPT.

\section{A. Randrup}

I. MUNKVAD

Sct. Hans Hospital, Department $E$,

Roskilde,

Denmark.

${ }^{1}$ Rech, R., J. Pharmacol. Exp. Therap., 146, 369 (1964).

${ }^{2}$ Quinton, R., and Halliwell, G., Nature, 200, 178 (1963).

${ }^{3}$ Spector, S., Sjoerdsma, A., and Udenfriend, S., J. Pharmacol. Exp. Therap. 147,86 (1965).

Randrup, A., Munkvad, I., and Udsen, P., Actx Pharmacol. Toxicol., 20 $145(1963)$.

${ }^{5}$ Randrup, A., and Munkvad, I., Psychopharmacologia, 7, 416 (1965).

- Randrup, A., and Munkvad, I. (in preparation).

? Leslie, G., and Maxwell, D., Brit. J. Pharmacol., 22, 301 (1964).

\section{Intraventricular Administration of Nalorphine to Mice implanted with Pellets of Morphine}

Whenever nalorphine is administered to white mice implanted with a pellet of morphine (base) an 'abstinence syndrome' is produced ${ }^{1}$. Its well-defined symptomatology and characteristics have been reported olsewhere ${ }^{2-4}$; the action of several drugs on the abstinence syndrome has also been tested ${ }^{5-7}$. However, its genesis is still not well understood. Bocause of this, it was thought of interest to determino whether nalorphine injected by the intraventricular route can elicit the abstinence syndrome in tolerant mice.

Male and female white mice weighing 25--30 g were divided into several groups of five animals each. Some groups were used as controls, while a morphine pellet was implanted in each mouse of the other groups; the daily absorption ranged between 90 and $130 \mathrm{mg} / \mathrm{kg}$ (ref. 1). Drugs were dissolved in physiological saline and administered in volumes of $0.025 \mathrm{ml}$. Intraventricular injections were performed according to the method of Haley and McCormick ${ }^{8}$ as modified by Adler ${ }^{9}$. The correct location of tho injected material was confirmed by (1) histological investigation after administration of indian ink; (2) by the appearance of the signs observed by Haley and McCormick immediately after a simple ventricular puncture or after the administration of saline and drugs (stupor, changes in tho tail position, hyperexcitability and oven slight convulsions $)^{8}$. Observation of the mice was discontinued $15-20 \mathrm{~min}$ after the intraventricular injection.

In control mice, intraventricular injection of nalorphine (25 and $50 \mu \mathrm{g} / \mathrm{kg}$ ) produced immobility or hypomotility during the first $5 \mathrm{~min}$, followed by the appearance of oxophthalmus, catatonia, and restlessness alternating with normal behaviour. The higher the dose, the more accontuated were the symptoms. Larger quantities $(100 \mu \mathrm{g} / \mathrm{kg})$ induced depression. Intraventricular injection of morphine $(50 \mu \mathrm{g} / \mathrm{kg})$ induced immobility in control mice; after $10 \mathrm{~min}$ some tail rigidity and restlessness were obscrved. Doses of $500 \mu \mathrm{g} / \mathrm{kg}$ elicited convulsions followed by a typical morphine syndrome.

In tolerant mice, an intraventricular injection of nalorphine was given 7-10 days after the implantation of morphine. This period was considored suitable for the development of an important degree of tolerance to and physical dependence on the alkaloid ${ }^{2}$. Doses ranging between 0.62 and $300 \mu \mathrm{g} / \mathrm{kg}$ were used (Table 1 ). 3-4 min after the administration of nalorphine the mice were able to move along if intensely stimulated; if undisturbed they lay motionless for 10-15 min. Furthermore, soft stools, micturition and restlessness were observed in many groups; these symptoms may be characterized as a dubious abstinence syndrome. When 200 and $300 \mu \mathrm{g} / \mathrm{kg}$ of nalorphine were administered, movements and positions typical of a weak abstinence syndrome could be observed, together with the aforementioned signs. When the same quantity of nalorphine was administered in a final volume of 0.01 